\title{
Late Roman cooking pottery from the Tavoliere area (Southern Italy): raw materials and technological aspects
}

\author{
Giacomo Eramo $^{\mathrm{a}}$, Rocco Laviano ${ }^{\mathrm{b}}$, Italo Maria Muntoni ${ }^{\mathrm{c}, *}$, Giuliano Volpe ${ }^{\mathrm{d}}$ \\ ${ }^{a}$ Institute of Mineralogy and Petrography, University of Fribourg, Pérolles, 1700 Fribourg, Switzerland \\ ${ }^{b}$ Dipartimento Geomineralogico, Università degli Studi di Bari, Via E. Orabona 4, 70125 Bari, Italy \\ ${ }^{c}$ Corso di, Laurea in Beni Culturali, Facultà di Lettere e Filosofia, Università degli Studi di Foggia, Piza R. Bonghi 38, 71036 Lucera (FG),Italy \\ ${ }^{d}$ Dipartimento di Scienze umane. Territorio, Beni culturali, Civiltà letterarie, Formazione, Università di Foggia, Via Arpi 155, 71100 Foggia, Italy
}

Received 3 March 2003; accepted 22 May 2003

\begin{abstract}
This study describes the results of petrographical, mineralogical and chemical analyses carried out on coarse tempered cooking pottery, sampled in the archaeological sites of Herdonia, Posta Crusta (Ordona, FG) and San Giusto (Lucera, FG). From the latter site, two fragments of a pottery kiln, coeval with sherds (IV and V centuries AD), were also investigated. Two groups of clayey sediments of different nature (alluvial and marine) sampled in the neighbouring of the archaeological sites were also analysed. By means of the petrographical analyses, all cooking pottery and the two kiln fragments were grouped in the same coarse tempered group, characterised by the scarce presence of trachytic and glassy fragments, anhedral and zoned augitic pyroxenes and feldspars. PXRD analyses show an abundant presence of quartz and feldspars, followed by pyroxenes and variable quantities of calcite and hematite. Among clay minerals, illite plus muscovite are more abundant than smectite. XRF analyses data display $\mathrm{SiO}_{2}, \mathrm{Al}_{2} \mathrm{O}_{3}, \mathrm{Fe}_{2} \mathrm{O}_{3}$ and $\mathrm{K}_{2} \mathrm{O}$ as main oxides, with variable quantities of $\mathrm{CaO}$. In the case of the clayey samples, petrographical investigations on thin-section of psammitic fractions outlined the differences between Argille subappennine (Marine group-Pleistocene) and the alluvial deposits of Celone River (Alluvial group—Holocene). The occurrence of volcanic products, chert, garnet, quartzarenites and limestones in the archaeological materials and in the alluvial samples, let us suppose that cooking pottery was made with alluvial clayey silt. The apparent chemical discordance between pottery and alluvial samples bulk compositions can be due to textural and compositional variability of the alluvial deposits. All ceramics were fired in oxidising conditions, although in many cases a "dark core" was still present. Textural features, observed through petrographical microscope, and PXRD analyses suggested a firing temperature between 600 and $800{ }^{\circ} \mathrm{C}$.
\end{abstract}

Keywords: Late Antique Age; Tavoliere; Cooking pottery; Pelitic samples; Archaeometry

\section{Introduction and research aims}

The Tavoliere plain is the most extensive alluvial basin in Southern Italy, it started to be inhabited from the Holocene and was densely settled between the Neolithic and the Middle Age. Optimal morphological and geological factors were the driving forces for anthropisation. The morphology of the marine and fluvial terraces and rivers occurrence allowed an easy cultivation. Plio-pleistocenic clayey sediments and alluvial deposits furnished raw materials for ceramic productions during this time [1-3].

The present archaeological and archaeometric researches are part of a bigger project carried out on the Late Roman

\footnotetext{
* Corresponding author.

E-mail address: imuntoni@katamail.com (I.M. Muntoni).
}

Age of Central-Northern Apulia at the University of Bari and Foggia and co-ordinated by G. Volpe [4,5]. In this project students with different cultural backgrounds (historians, epigraphists, archaeologists, archaeometorists, geophysicists) are involved. The most important aspect of this research is the different sources and approaches utilised, such as historical, archaeological, archaeometric and geophysical methodologies, with the aim to give an answer to several questions and to solve specific historical problems. The research intends to point out the deep transformations that took place during the Late Roman Age, with reference to the settlement types (towns, villas, farms, villages, etc.), to the institutional and administrative forms, to the Christianization of towns and countryside, to the variety of the landscapes, to the agricultural craft made and breeding production manage- 


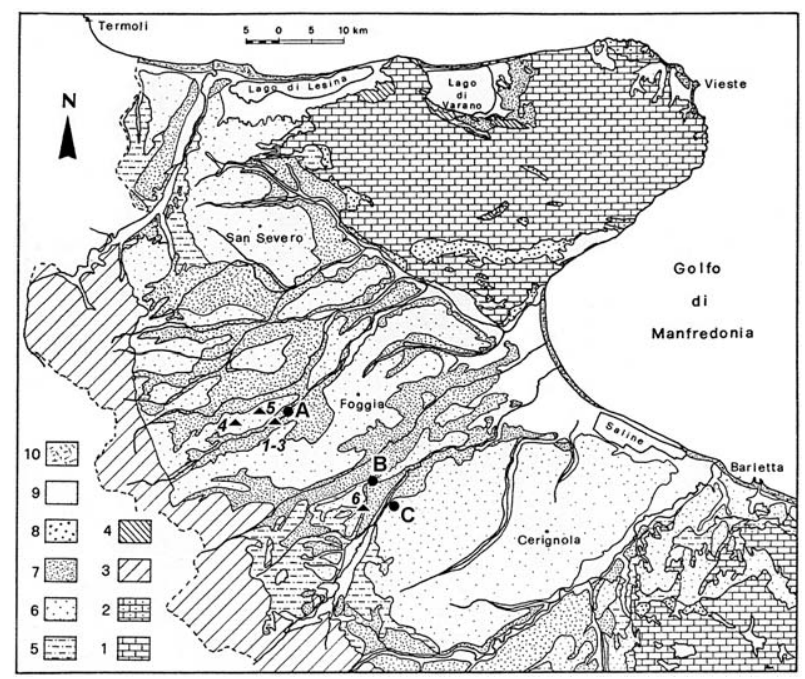

Fig. 1. Localisation of the archaeological sites of San Giusto (A), Posta Crusta (B) and Herdonia (C), and of the six pelitic samples of alluvial (1-3. GEC5, GEC7 and GEC8) and marine (4. GEC3; 5. GEC4; 6. GEC2) clays (from Caldara, Pennetta [6], modified): (1) Mesozoic bedrock; (2) Eocenic calcarenites; (3) Apenninic Chain Units (from pre-to late orogenic); (4) Miocenic calcarenites; (5) Bradano Units (Pliocene-Lower Pleistocene); (6) Terraced marine deposits (Upper-Middle Pleistocene); (7) Terraced alluvial deposits (Upper Pleistocene); (8) Talus breccias and eluvial deposits (Holocene); (9) Alluvial and lacustrine deposits (Holocene); (10) Beach and coastal dunes (Holocene).

ment, to the circulation and/or importation networks and to the local and regional productions of goods.

The archaeological materials studied here came from three different settlement typologies in Late Roman Apulia: a town named Herdonia (Ordona municipality, in the province of Foggia), a village named San Giusto (Lucera municipality, in the province of Foggia), and finally a villa named Posta Crusta in the Herdonian territory (Fig. 1). This paper displays the results of the mineralogical and chemical investigations of 15 cooking pottery and two kiln fragments. Six samples of different clayey sediments exploitable in ceramic productions were also investigated. The aims are to verify the archaeological hypothesis of a local production and to infer some technological aspect about ceramic production.

Herdonia's archaeological excavation started in 1962. It was directed by J. Mertens from Leuven University, with the successive co-operation of Bari University and the current supervision of G. Volpe from Foggia University. This settlement lived with several transformations from Iron Age throughout the Medieval Age [7,8]. The ancient Roman town of Herdonia started its development since III century BC and reached its maximum extension during the early Imperial Age (I-II century AD), thanks to the Via Traiana one of the most important roads in Southern Italy. At the beginning of the 1970s an excavation campaign was carried out by the Belgian mission at the Posta Crusta villa $[9,10]$. The farm, which was assigned essentially to olive oil production, was a long-lived settlement with several habitation phases dated between the II century $\mathrm{BC}$ and the VI century AD. The findings, such as common and fire-resisting pottery, here presented come from late-roman layers and belong to a Herdonian domus and Posta Crusta villa, both very recently published [11-13].

A particularly important archaeological site in Northern Apulia is San Giusto, one of the best-known rural villages of Southern Italy, which has unfortunately been irremediably submersed by the Celone dam waters $[14,15]$. In this rural site are present the typical features of a productive rural settlement of the Imperial Age (a villa; I-VI century AD) and of an artisan centre of Late Roman Age (with the construction of a pottery kiln; V-VI century AD) together with an important religious building (a Bishop residence?) i.e. a double basilica, furnished with a baptistery (V-VII century AD). The presence of a late roman kiln (a 1/a type according to the classification proposed by Cuomo di Caprio [16]) gives to the archaeologists a great opportunity to classify the local common pottery and guarantees a further important support to the archaeometric investigation.

\section{Analytical methods}

The fabric analysis on thin-section of archaeological samples was conducted by means of a petrographical microscope, distinguishing among temper, matrix and voids characters [17]. Modal analyses were carried out through a point counter Swift \& S., with a line distance of $0.05 \mathrm{~mm}$ and a lateral step of $0.2 \mathrm{~mm}$.

Each sample was powdered in a agate mortar and successively subjected to powder X-ray diffraction (PXRD) and $\mathrm{X}$-ray fluorescence (XRF). PXRD analyses were carried out through a Philips 1730/10 powder diffractometer, with $\mathrm{Cuk}_{\alpha}$ radiation filtered on Ni. XRF analyses were conducted through a Philips PW 1410 spectrometer. Two reference standards (AGV-1 of USGS-USA and NIM-G of NIM-South Africa) were used to check the accuracy of the analytical data. Loss of ignition was determined by heating at $1000{ }^{\circ} \mathrm{C}$ for $12 \mathrm{~h}$. PXRD patterns of previously heated samples, for the identification of mineralogical changes, were recorded at room temperature. Correction of matrix effects was made through computer processing [18].

With regard to the raw materials, a granulometrical separation by sedimentation, according to the method proposed by Laviano [19], was processed. A distinction among clay $(<2 \mu \mathrm{m})$, silt $(2-63 \mu \mathrm{m})$ and sand $(>63 \mu \mathrm{m})$ fractions was obtained. Psammitic fractions of pelitic samples were analysed on thin-section. PXRD analyses were carried out on "tout venant" sample, while XRF analyses on "tout venant" sample and on clay fraction $(<2 \mu \mathrm{m})$.

\section{Cooking pottery and kiln fragments}

Cooking pottery samples came from three different archaeological sites in the Tavoliere area (Foggia, Italy). Eleven samples come from Herdonia and S. Giusto. The six 
sherds from Herdonia (HE1-6) were found in a cisterna that was filled in a very short time. In the case of S. Giusto, three potsherds (SG1-3) found near the pottery kiln and two fragments (SGK1-2) of the same kiln were sampled. Six samples from Posta Crusta (PC1-6) were selected typologically among cooking potteries. All samples are dated between IV and V century AD.

\subsection{Optical microscopy analysis}

All samples can be grouped in the same petrographic group for the common occurrence of volcanic materials (Volcanic Group). Different texture and relative amount of carbonatic grains allow the dividing of the samples in two subgroups: (Va) coarse temper with abundant matrix (cooking pottery) and ( $\mathrm{Vc}$ ) very coarse temper with carbonatic grains (kiln fragments).

\subsubsection{Subgroup Va}

The samples show a homogeneously distributed coarse temper (max. dim. $5.7 \mathrm{~mm}$ ). The temper composition is primarily represented by quartz, feldspars and volcanic rock fragments and by minor amounts of clinopyroxene, amphibole, micas, calcite, garnet, opaque minerals and ferruginous aggregates. Fine-grained quartz shows angular shape as opposed to coarse mono- and polycrystalline ones. Among polycrystalline quartz grains, quartzarenite, quartzite and chert occur. Feldspars are scarcely altered and alkalifeldspars are more abundant than plagioclase (mostly oligoclase). Their habits are often subhedral or anhedral and crystal grains show glassy inclusions and zoned rims. Two types of clinopyroxenes were distinguished on thin-section: colourless and non-pleochroic augites, and green pleochroic aegirine-augites. The amphibole has a strong pleochroism (deep to pale brown), columnar habit and inclined extinction $\left(c^{\wedge} \gamma^{\prime} \sim 19^{\circ}\right)$. Among micas, muscovite crystals are more abundant than biotite. Primary and secondary calcite, as pore filling, is present in the ceramic bodies. Bioclasts, benthonic foraminifer shells and biomicrite clasts were sometimes observed. Small quantities of iron oxy-hydroxide and silt aggregates, mainly with internal concentric structure, occur in all samples. High optical density and sub-circular shape are the distinctive characters. The volcanic rock fragments are represented by trachytic rounded clasts and vesiculated glass. Two types of trachytic fragments occur: hypocrystalline trachyte (Fig. 2) with feldspar microfenocrysts, magnetite and clinopyroxene; hypoialine trachyte, more alterated and rounded than the former one, with isoriented feldspar crystallites in a glassy ground mass. Volcanic glass fragments have brownish colour and different degree of vesiculation.

The matrix content goes over $60 \%$ in volume and the ceramic bodies often shows chromatic zoning due to a different oxidation grade of the matrix. The occurrence of a dark core less birefringent than the more birefringent brownorange rim is a common pattern. Only sample HE4 has a homogeneous orange colour and birefringence.

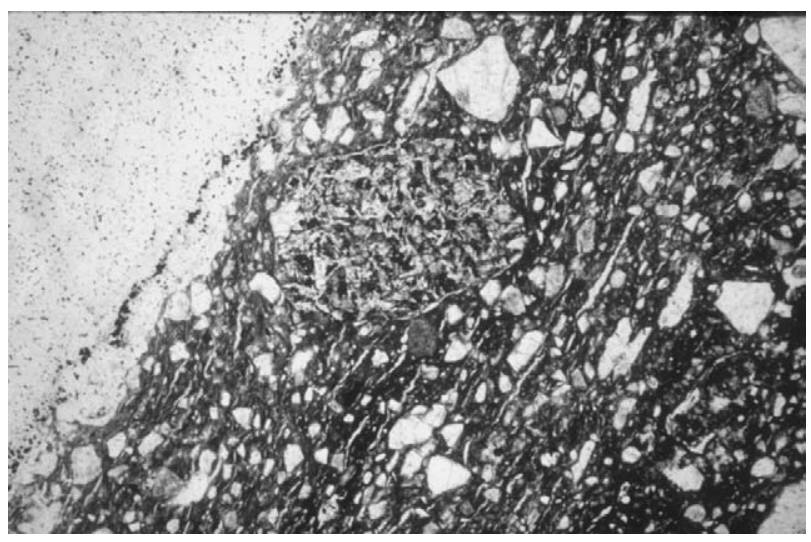

Fig. 2. Photomicrograph of pottery sample PC6 with a hypocrystalline trachytic fragment (40× magnification, plane-polarised light). Top-left portion of picture (white portion): supporting glass of thin-section.

Within the matrix, two types of voids are detected: primary porosity due to manipulation and drying shrinkage due to drying and firing. The former is characterised by a geometrically complex contour with an elongated shape, often parallel to the sherd surfaces. The latter is sub-parallel to the sherd surfaces or rounds the temper grains. Drying shrinkage is often smaller then primary porosity which has a frequent millimetric dimension.

\subsubsection{Subgroup $V c$}

The two kiln fragments have pebbles and sand temper homogeneously distributed (30-40\%). The temper composition is principally calcareous (micritic bioclasts, limestone clasts and fine-grained calcite), with minor amount of quartz, feldspars, clinopyroxene, amphibole, volcanic rock fragments, micas, garnet and oxides aggregates. The matrix has a homogeneous orange colour with primary and secondary porosity. Drying shrinkage has a random orientation.

\subsubsection{Modal analysis}

In order to get a quantitative characterisation of the samples of the two subgroups, modal analyses were carried out. Only some significant body components (Table 1) were counted. With regard to quartz, fine $(15-63 \mu \mathrm{m})$, coarse (>63 $\mu \mathrm{m})$ and polycrystalline classes were differentiated. Chert was considered as polycrystalline quartz. The percentages of the volcanic rock fragments are listed as VRF. Ferruginous aggregates and ooids were counted in the same class. The mean values depict the differences between the subgroups, as well as a certain correspondence in pyroxenes and volcanic rock fragments.

\subsection{PXRD analyses}

Mineralogical differences observed on thin-section seem to be confirmed by PXRD analyses (Table 2). Variable clay minerals content was detected in all samples, while the most intensity peaks of calcite are either low or absent. Weak peaks of hematite occur in two samples (PC2 and HE1) of cooking pottery and in the kiln fragment SGK1. PXRD 
Table 1

Modal analyses (vol. \%) of archaeological samples

\begin{tabular}{|c|c|c|c|c|c|c|c|c|c|c|c|c|c|}
\hline Samples & Matrix & Voids & $\begin{array}{l}\text { Fine } \\
\text { Qtz }\end{array}$ & $\begin{array}{l}\text { Coarse } \\
\text { Qtz }\end{array}$ & $\begin{array}{l}\text { Poly- } \\
\text { crystalline } \\
\text { Qtz }\end{array}$ & $\begin{array}{l}\text { Total } \\
\text { Qtz }\end{array}$ & Feld & VRF & Micas & Cal & Px & $\begin{array}{l}\text { Opaque } \\
\text { minerals }\end{array}$ & Ooids \\
\hline PC1 & 70.50 & 6.30 & 8.90 & 3.40 & 1.40 & 13.70 & 5.00 & 1.90 & 1.00 & 0.00 & 0.50 & 0.00 & 1.10 \\
\hline PC2 & 66.50 & 9.60 & 7.10 & 4.80 & 3.40 & 15.30 & 3.90 & 0.40 & 0.90 & 2.30 & 0.20 & 0.00 & 0.90 \\
\hline PC3 & 70.30 & 7.80 & 5.40 & 4.10 & 1.20 & 10.70 & 4.50 & 2.60 & 1.00 & 2.00 & 0.40 & 0.20 & 0.50 \\
\hline PC4 & 62.90 & 7.90 & 5.10 & 2.00 & 1.30 & 8.40 & 5.80 & 10.70 & 0.50 & 0.50 & 0.80 & 0.80 & 1.70 \\
\hline PC5 & 72.00 & 8.80 & 3.10 & 1.30 & 0.70 & 5.10 & 8.80 & 2.30 & 0.20 & 0.50 & 0.40 & 0.50 & 1.40 \\
\hline PC6 & 64.20 & 10.60 & 9.30 & 5.20 & 2.20 & 16.70 & 5.50 & 1.40 & 0.50 & 0.30 & 0.40 & 0.20 & 0.20 \\
\hline$X$ & 67.73 & 8.50 & 6.48 & 3.47 & 1.70 & 11.65 & 5.58 & 3.22 & 0.68 & 0.93 & 0.45 & 0.28 & 0.97 \\
\hline HE1 & 64.80 & 8.10 & 5.60 & 1.50 & 0.60 & 7.70 & 14.00 & 2.40 & 0.30 & 0.30 & 1.00 & 1.10 & 0.30 \\
\hline HE2 & 68.90 & 5.90 & 7.10 & 0.80 & 0.70 & 8.60 & 11.00 & 2.30 & 1.10 & 0.30 & 1.20 & 0.40 & 0.30 \\
\hline HE3 & 66.60 & 7.05 & 4.00 & 1.00 & 1.10 & 6.10 & 10.75 & 2.10 & 0.50 & 4.60 & 0.70 & 0.30 & 1.30 \\
\hline HE4 & 60.50 & 9.90 & 8.20 & 6.80 & 2.20 & 17.20 & 7.00 & 0.60 & 0.60 & 2.90 & 0.40 & 0.60 & 0.30 \\
\hline HE6 & 74.23 & 6.71 & 4.58 & 2.45 & 1.38 & 8.41 & 1.92 & 4.37 & 1.60 & 0.21 & 0.43 & 0.21 & 1.92 \\
\hline$X$ & 67.82 & 7.54 & 6.31 & 2.41 & 1.06 & 9.79 & 8.21 & 2.11 & 0.88 & 1.57 & 0.70 & 0.49 & 0.89 \\
\hline SG1 & 68.50 & 6.10 & 7.40 & 1.90 & 0.30 & 9.60 & 7.60 & 1.10 & 0.50 & 1.00 & 2.40 & 2.30 & 0.90 \\
\hline SG2 & 70.20 & 4.70 & 7.20 & 1.50 & 0.40 & 9.10 & 9.40 & 1.10 & 0.60 & 1.30 & 2.00 & 1.20 & 0.40 \\
\hline SG3 & 70.10 & 4.70 & 6.30 & 1.40 & 0.40 & 8.10 & 10.10 & 1.00 & 1.20 & 2.30 & 1.60 & 0.50 & 0.40 \\
\hline$X$ & 69.60 & 5.17 & 6.97 & 1.60 & 0.37 & 8.93 & 9.03 & 1.07 & 0.77 & 1.53 & 2.00 & 1.33 & 0.57 \\
\hline$X(\mathrm{PC}+\mathrm{HE}+\mathrm{SG})$ & 68.14 & 7.45 & 6.51 & 2.67 & 1.18 & 10.36 & 7.32 & 2.34 & 0.78 & 1.31 & 0.86 & 0.57 & 0.85 \\
\hline SGK1 & 53.27 & 15.77 & 2.21 & 1.14 & 0.10 & 3.45 & 11.98 & 4.04 & 1.04 & 8.08 & 1.06 & 0.88 & 0.00 \\
\hline SGK2 & 43.29 & 14.90 & 3.20 & 1.20 & 0.30 & 4.70 & 10.90 & 1.20 & 0.40 & 23.35 & 0.70 & 0.50 & 0.10 \\
\hline$X$ & 48.28 & 15.34 & 2.71 & 1.17 & 0.20 & 4.08 & 11.44 & 2.62 & 0.72 & 15.72 & 0.88 & 0.69 & 0.05 \\
\hline
\end{tabular}

Qtz, quartz; Feld, k-feldspar and plagioclase; VRF, volcanic rock fragments; Cal, calcite; Px, pyroxenes (symbols as in Kretz [20]).

Table 2

Mineralogical composition, by PXRD analysis, of archaeological samples in its as-received state and after refiring at $1000{ }^{\circ} \mathrm{C}$

\begin{tabular}{|c|c|c|c|c|c|c|c|c|c|c|}
\hline \multirow[t]{2}{*}{ Samples } & \multicolumn{5}{|c|}{ As-received } & \multicolumn{5}{|c|}{ Refired at $1000^{\circ} \mathrm{C}$} \\
\hline & C.M. & Qtz & Feld & $\mathrm{Cal}$ & Hem & Qtz & Feld & Px & Gh & Hem \\
\hline PC1 & $*$ & $* * * * *$ & $* *$ & I & I & $* * * * *$ & $* * *$ & I & I & $*$ \\
\hline $\mathrm{PC} 2$ & * & $* * * * *$ & $* * *$ & $*$ & $*$ & $* * * * *$ & $* * *$ & I & l & $*$ \\
\hline PC3 & l & $* * * *$ & $* *$ & l & I & $* * * *$ & $* *$ & $*$ & l & $*$ \\
\hline PC4 & $* *$ & $* * * *$ & $* *$ & $*$ & l & $* * * *$ & $* * *$ & $*$ & l & $*$ \\
\hline PC5 & $*$ & $* * *$ & $* *$ & l & l & $* * *$ & $* * *$ & $*$ & l & $*$ \\
\hline PC6 & l & $* * *$ & $* *$ & l & l & $* * *$ & $* * * *$ & $*$ & l & $*$ \\
\hline HE1 & $* *$ & $* * * *$ & $* * *$ & / & $*$ & $* * * *$ & $* * *$ & $*$ & l & $*$ \\
\hline HE2 & * & $* * * *$ & $* *$ & I & I & $* * * *$ & $* * *$ & I & I & $*$ \\
\hline HE3 & $*$ & $* * *$ & $* * * *$ & $*$ & I & $* * *$ & $* * *$ & $* *$ & I & $*$ \\
\hline HE4 & $* *$ & $* * * * *$ & $* * *$ & $*$ & I & $* * * * *$ & $* * *$ & $*$ & $*$ & $*$ \\
\hline HE5 & I & $* * *$ & $* *$ & 1 & I & $* * *$ & $* * *$ & $*$ & I & $*$ \\
\hline HE6 & I & $* * *$ & $* *$ & I & 1 & $* * *$ & $* * *$ & 1 & I & $*$ \\
\hline SG1 & $* * *$ & $* * * *$ & $* * *$ & $* *$ & I & $* * * *$ & $* * *$ & $*$ & I & $*$ \\
\hline SG2 & I & $* * * *$ & $* * *$ & $*$ & I & $* * * *$ & $* * *$ & $*$ & I & $*$ \\
\hline SG3 & I & $* * * *$ & $* *$ & $*$ & I & $* * * *$ & $* * * *$ & $*$ & $*$ & $*$ \\
\hline SGK1 & $* *$ & $* * *$ & $* *$ & $* *$ & $*$ & $* * *$ & $* * *$ & $*$ & I & $*$ \\
\hline SGK2 & $*$ & $* *$ & $*$ & $* * * *$ & I & $* *$ & $* *$ & $*$ & $*$ & I \\
\hline
\end{tabular}

C.M., clay minerals; Qtz, quartz; Feld, k-feldspar + plagioclase; Cal, calcite; Hem, hematite; Px, pyroxenes; Gh, gehlenite (symbols as in Kretz [20]). Number of $(*)$ is in relationship with mineralogical phase abundance. 
Table 3

Chemical composition (wt \%) of archaeological samples by XRF analysis

\begin{tabular}{|c|c|c|c|c|c|c|c|c|c|c|c|}
\hline Samples & $\mathrm{SiO}_{2}$ & $\mathrm{TiO}_{2}$ & $\mathrm{Al}_{2} \mathrm{O}_{3}$ & $\mathrm{Fe}_{2} \mathrm{O}_{3}$ & $\mathrm{MnO}$ & $\mathrm{MgO}$ & $\mathrm{CaO}$ & $\mathrm{Na}_{2} \mathrm{O}$ & $\mathrm{K}_{2} \mathrm{O}$ & $\mathrm{P}_{2} \mathrm{O}_{5}$ & LOI \\
\hline PC1 & 64.09 & 0.69 & 19.18 & 5.94 & 0.10 & 1.98 & 1.84 & 1.19 & 3.54 & 0.13 & 1.32 \\
\hline PC2 & 61.10 & 0.66 & 17.06 & 6.25 & 0.09 & 1.98 & 5.74 & 0.82 & 2.87 & 0.17 & 3.26 \\
\hline PC3 & 62.51 & 0.76 & 18.80 & 6.26 & 0.10 & 1.44 & 2.75 & 0.81 & 2.99 & 0.13 & 3.45 \\
\hline PC4 & 62.99 & 0.69 & 17.63 & 5.91 & 0.05 & 1.34 & 2.46 & 0.80 & 3.04 & 0.11 & 4.98 \\
\hline PC5 & 63.53 & 0.76 & 20.02 & 6.51 & 0.15 & 1.51 & 1.59 & 1.04 & 3.10 & 0.07 & 1.72 \\
\hline PC6 & 67.19 & 0.62 & 17.80 & 5.36 & 0.03 & 1.67 & 1.66 & 1.16 & 3.11 & 0.17 & 1.23 \\
\hline$x$ & 63.57 & 0.70 & 18.42 & 6.04 & 0.09 & 1.65 & 2.67 & 0.97 & 3.11 & 0.13 & 2.66 \\
\hline HE1 & 62.86 & 0.64 & 17.69 & 5.82 & 0.10 & 1.46 & 1.88 & 0.92 & 3.69 & 0.18 & 4.76 \\
\hline HE2 & 66.12 & 0.70 & 18.23 & 6.10 & 0.07 & 1.63 & 1.43 & 1.06 & 3.16 & 0.06 & 1.44 \\
\hline HE3 & 61.48 & 0.68 & 17.76 & 5.91 & 0.08 & 1.86 & 4.35 & 1.04 & 3.29 & 0.15 & 3.40 \\
\hline HE4 & 58.54 & 0.56 & 16.69 & 5.99 & 0.07 & 1.63 & 7.30 & 0.73 & 2.89 & 0.19 & 5.41 \\
\hline HE5 & 64.71 & 0.74 & 18.62 & 6.36 & 0.08 & 1.69 & 1.90 & 0.94 & 3.15 & 0.10 & 1.71 \\
\hline HE6 & 63.89 & 0.75 & 19.04 & 6.57 & 0.12 & 2.12 & 1.87 & 1.13 & 3.42 & 0.07 & 1.02 \\
\hline SG1 & 59.51 & 0.72 & 16.02 & 6.12 & 0.17 & 2.55 & 5.58 & 0.85 & 3.35 & 0.14 & 4.99 \\
\hline SG2 & 61.46 & 0.73 & 16.59 & 6.37 & 0.17 & 2.47 & 5.96 & 1.11 & 3.25 & 0.19 & 1.70 \\
\hline SG3 & 61.25 & 0.73 & 16.35 & 6.28 & 0.17 & 2.60 & 5.76 & 0.92 & 3.24 & 0.16 & 2.54 \\
\hline$x$ & 60.74 & 0.73 & 16.32 & 6.26 & 0.17 & 2.54 & 5.77 & 0.96 & 3.28 & 0.16 & 3.08 \\
\hline$X(\mathrm{PC}+\mathrm{HE}+\mathrm{SG})$ & 62.75 & 0.70 & 17.83 & 6.12 & 0.10 & 1.86 & 3.47 & 0.97 & 3.21 & 0.13 & 2.86 \\
\hline SGK1 & 52.95 & 0.74 & 16.25 & 6.23 & 0.19 & 2.17 & 8.28 & 0.73 & 3.20 & 0.18 & 9.08 \\
\hline SGK2 & 36.13 & 0.46 & 8.95 & 3.78 & 0.17 & 1.48 & 26.72 & 0.52 & 1.81 & 0.42 & 19.56 \\
\hline$x$ & 44.54 & 0.60 & 12.60 & 5.01 & 0.18 & 1.83 & 17.50 & 0.63 & 2.51 & 0.30 & 14.32 \\
\hline
\end{tabular}

values for quartz quantities are clearly higher than those obtained by the modal analyses, because abundant finegrained quartz $(<15 \mu \mathrm{m})$ is present in the matrix. PXRD analyses of $1000{ }^{\circ} \mathrm{C}$ heat-treated samples display the occurrence of new-formed pyroxenes, feldspars and hematite in almost all samples. In some case (HE4, SG3 and SGK2), weak peaks of gehlenite were detected.

\subsection{XRF analyses}

The concentration of minor and trace elements (Table 3) were useful to identify affinity among sherds. $\mathrm{SiO}_{2}, \mathrm{Al}_{2} \mathrm{O}_{3}$, $\mathrm{Fe}_{2} \mathrm{O}_{3}$ and $\mathrm{K}_{2} \mathrm{O}$ were the more abundant oxides. The $\mathrm{CaO}$ concentrations are generally low, except for those of subgroup $\mathrm{Vc}(>8 \%)$. All the samples have been plotted on the ternary diagram $\mathrm{CaO} / \mathrm{SiO}_{2} / \mathrm{Al}_{2} \mathrm{O}_{3}$ and all samples can be defined as "Ca-poor", except for the two kiln fragments ("Ca-rich"). $\mathrm{Fe}_{2} \mathrm{O}_{3}$ and $\mathrm{K}_{2} \mathrm{O}$ concentrations are rather homogeneous except in $\mathrm{SGK} 2$.

\section{Pelitic samples}

Two different types of clayey materials exploitable in pottery production occur in the surroundings of the archaeological sites: alluvial deposits and Argille subappennine (emipelagic sediments) [21,22]. From each formation three specimens were sampled. The three alluvial samples (GEC5, GEC7 and GEC8) were collected in Holocene alluvial depo- sits of the Celone River (Alluvial Group), $2 \mathrm{~km} \mathrm{SW}$ from S. Giusto where the pottery kiln used during the IV-V century AD was identified. The three Argille subappennine samples (GEC2, GEC3 and GEC4) were collected taking into account the ancient road network, because of the relative longer distance of the outcrops (Marine Group) from the sites (Fig. 1): GEC2 was sampled $6 \mathrm{~km}$ WSW from Herdonia (at the cross-road between SS161 and SS655), GEC3 was sampled at M. Croce ( $8 \mathrm{~km} \mathrm{~W}$ from S. Giusto) and GEC4 at M. Ripatetta (5 km WNW from S. Giusto). The two clayey materials showed different colours and plasticity: the alluvial samples are brown-grey (wet) coloured, whereas the marine ones are yellow-grey (wet). In the Shepard's ternary diagram (Fig. 3) all samples fall in the "clayey silt" area, except for GEC7 which is classified as "silt". Group M specimens are richer in sand than Group A.

\subsection{Optical microscopy analyses}

The sandy fraction of each specimen was observed on thin-section. The two raw materials groups show different mineralogical and petrographic contents: (M) carbonatic clasts, (A) silicatic and volcanic clasts.

Group A has volcanic minerals and rock fragments as distinctive presence. In general, it is lower than $10 \%$ in volume of the sand (Table 4). Heavy minerals are represented by dominant pyroxene, amphibole, magnetite, biotite and garnet. Clinopyroxenes are colorless and non-pleochroic augite and pleochroic on green tones aegirine-augite types. 


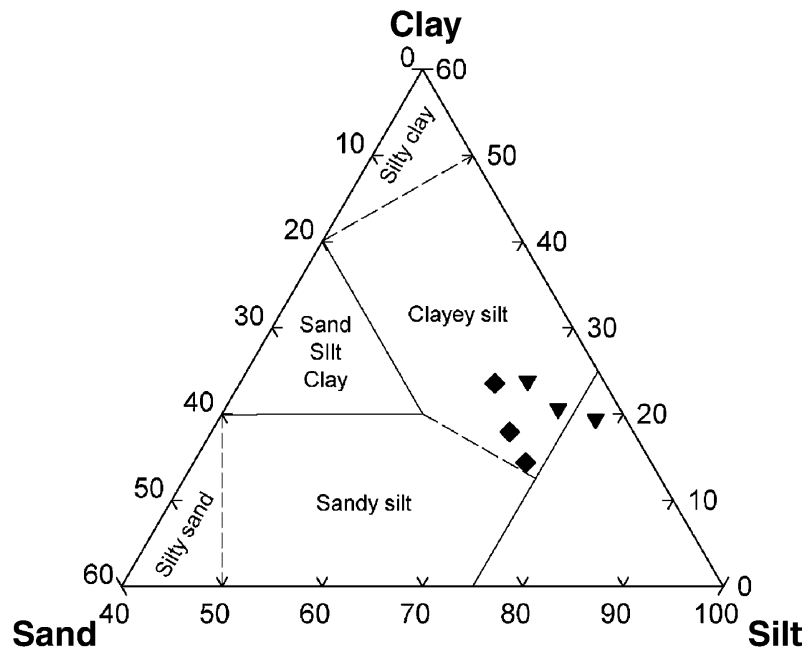

Fig. 3. Shepard's ternary diagram of pelitic samples. Diamonds: Argille subappennine (Marine group); triangles: Alluvial deposits (Alluvial group).

Magnetite crystals occur as inclusions and loosely crystals. Crystals of brown horneblende show strong pleochroism on brown tones and low extinction angles. Biotite has pseudorect extinction and strong pleochroism. Garnet shows high optical relief, pale yellow colour and total extinction at crossed polars. Several feldspars show effusive origins (e.g. irregular twinning, anhedral habit, etc). Furthermore, few clasts of trachytic rock and volcanic glass were detected (Fig. 4). Micritic bioclasts, chert, quartz and minor amounts of iron ooids and ferruginous aggregates constitute the most part of sandy fraction.

Mineralogical features suggest a volcanic origin (i.e. tephra, epiclastite) for heavy minerals and part of the feldspars (i.e. sanidine, oligoclase). Mono- and poli-crystalline quartz (i.e. quartzarenite, chert) has a sedimentary origin.

For what concerns Group M, the coarse fractions are composed of abundant quartz, micritic bioclasts (e.g., algae, benthonic foraminiphera, bivalves, etc.), feldspars and round-shaped iron oxides and silt aggregates.

\subsection{XRD analyses}

The two raw material groups have different mineralogical compositions (Table 4). Group A is characterised by relative

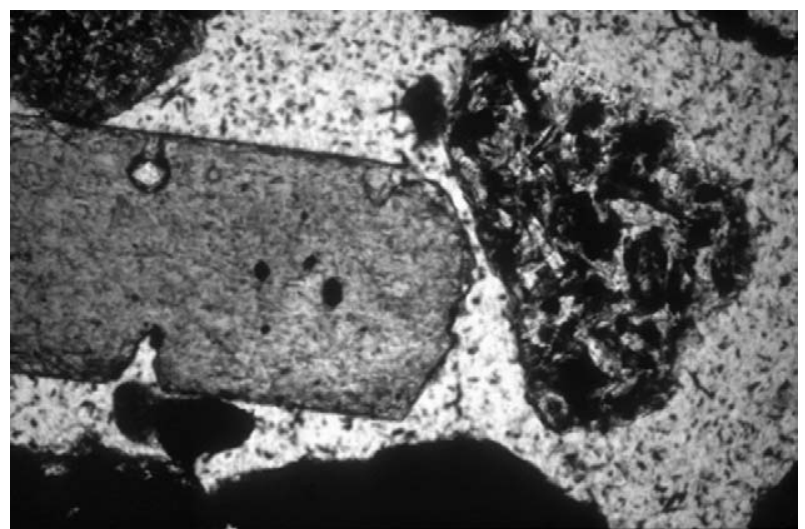

Fig. 4. Photomicrograph of psammitic fraction of alluvial sample GEC7 with a prismatic aegirine-augite (left) and a hypocrystalline trachytic fragment (right) (160× magnification, plane-polarised light). White portion of picture: supporting glass of thin-section.

high content of calcite, whereas Group $M$ is richer in quartz and feldspars. Alluvial samples (Group A) are richer in clay minerals (smectite and illite/muscovite) than the Marine ones (Group M).

\subsection{XRF analyses}

Bulk composition and clay fraction $(<2 \mu \mathrm{m})$ were analysed for each sample. All specimens were characterised by the relative abundance of $\mathrm{SiO}_{2}, \mathrm{Al}_{2} \mathrm{O}_{3}, \mathrm{CaO}, \mathrm{Fe}_{2} \mathrm{O}_{3}, \mathrm{~K}_{2} \mathrm{O}$ and $\mathrm{MgO}$ (Table 5). Marly clays constitute both groups. In general, fractions finer than $2 \mu \mathrm{m}$ have a lower $\mathrm{CaO}$ content than the whole specimens, while the $\mathrm{Fe}_{2} \mathrm{O}_{3}$ concentration is higher.

\section{Discussion and conclusions}

Mineralogical and petrographic data allowed the grouping of the 15 cooking pottery and the two kiln fragments into the same volcanic class (V). On the basis of the calcite contents, it was possible to distinguish a Subgroup Va formed by all the pottery samples and a Subgroup Vc formed by kiln fragments only. A total of six specimens of two possible raw materials were collected in the surroundings of the archaeological

Table 4

Granulometric and PXRD analyses of pelitic samples

\begin{tabular}{|c|c|c|c|c|c|c|c|c|c|c|c|}
\hline & Samples & Sand & Silt & Clay & $\mathrm{Sm}$ & $\mathrm{Ill}+\mathrm{Ms}$ & Kln & Qtz & Feld & $\mathrm{Cal}$ & Do \\
\hline & & $(>63 \mu \mathrm{m})$ & $(2-63 \mu \mathrm{m})$ & $(<2 \mu \mathrm{m})$ & & & & & & & \\
\hline \multirow[t]{4}{*}{ Marine group } & GEC2 & 12.34 & 69.73 & 17.93 & 14 & 9 & 20 & 42 & 2 & 12 & 1 \\
\hline & GEC3 & 11.01 & 65.43 & 23.56 & 6 & 7 & 3 & 58 & 10 & 13 & 3 \\
\hline & GEC4 & 12.51 & 73.11 & 14.38 & 28 & 20 & 6 & 27 & 2 & 14 & 3 \\
\hline & $x$ & 11.95 & 69.43 & 18.62 & 16 & 12 & 10 & 42 & 5 & 13 & 2 \\
\hline \multirow[t]{4}{*}{ Alluvial group } & GEC5 & 7.63 & 68.56 & 23.81 & 46 & 14 & 5 & 16 & 3 & 15 & 1 \\
\hline & GEC7 & 3.04 & 77.55 & 19.41 & 18 & 14 & 4 & 32 & 2 & 29 & 1 \\
\hline & GEC8 & 6.16 & 73.23 & 20.61 & 22 & 18 & 5 & 40 & 2 & 12 & 1 \\
\hline & $x$ & 5.61 & 73.11 & 21.28 & 29 & 15 & 5 & 29 & 2 & 19 & 1 \\
\hline
\end{tabular}

Sm, smectite; Ill + Ms, illite + muscovite; Kln, kaolinite; Qtz, quartz; Feld, k-feldspar + plagioclase; Cal, calcite; Do, dolomite (symbols as in Kretz [20]). 
Table 5

Chemical composition (wt \%) of pelitic samples by XRF analysis

\begin{tabular}{|c|c|c|c|c|c|c|c|c|c|c|c|c|}
\hline & Samples & $\mathrm{SiO}_{2}$ & $\mathrm{TiO}_{2}$ & $\mathrm{Al}_{2} \mathrm{O}_{3}$ & $\mathrm{Fe}_{2} \mathrm{O}_{3}$ & $\mathrm{MnO}$ & $\mathrm{MgO}$ & $\mathrm{CaO}$ & $\mathrm{Na}_{2} \mathrm{O}$ & $\mathrm{K}_{2} \mathrm{O}$ & $\mathrm{P}_{2} \mathrm{O}_{5}$ & LOI \\
\hline \multicolumn{13}{|l|}{ Marine group } \\
\hline \multirow[t]{4}{*}{ "tout venant" } & GEC2 & 50.26 & 0.70 & 13.99 & 6.36 & 0.13 & 1.78 & 11.14 & 0.59 & 2.21 & 0.22 & 12.62 \\
\hline & GEC3 & 45.28 & 0.64 & 13.16 & 5.44 & 0.10 & 3.08 & 13.75 & 0.93 & 2.11 & 0.23 & 15.28 \\
\hline & GEC4 & 45.04 & 0.61 & 12.40 & 5.33 & 0.09 & 2.50 & 15.07 & 0.77 & 1.85 & 0.25 & 16.09 \\
\hline & $x$ & 46.86 & 0.65 & 13.18 & 5.71 & 0.11 & 2.45 & 13.32 & 0.76 & 2.06 & 0.23 & 14.66 \\
\hline \multirow[t]{4}{*}{$<2 \mu \mathrm{m}$} & GEC2a & 45.87 & 0.82 & 17.78 & 9.51 & 0.14 & 2.46 & 6.56 & 0.22 & 2.50 & 0.12 & 14.02 \\
\hline & GEC3a & 45.36 & 0.82 & 17.47 & 7.30 & 0.08 & 3.21 & 7.75 & 0.26 & 2.47 & 0.11 & 15.17 \\
\hline & GEC4a & 42.77 & 0.73 & 16.63 & 8.18 & 0.07 & 3.10 & 7.90 & 0.26 & 2.15 & 0.12 & 18.09 \\
\hline & $x$ & 44.67 & 0.79 & 17.29 & 8.33 & 0.10 & 2.92 & 7.40 & 0.25 & 2.37 & 0.12 & 15.76 \\
\hline \multicolumn{13}{|l|}{ Alluvial group } \\
\hline \multirow[t]{3}{*}{ "tout venant" } & GEC5 & 37.41 & 0.58 & 11.32 & 5.03 & 0.11 & 2.04 & 18.92 & 0.42 & 1.59 & 0.30 & 22.28 \\
\hline & GEC7 & 40.49 & 0.56 & 10.53 & 4.45 & 0.14 & 1.91 & 18.30 & 0.57 & 1.63 & 0.31 & 21.11 \\
\hline & $x$ & 39.62 & 0.57 & 10.97 & 4.71 & 0.13 & 2.01 & 18.15 & 0.52 & 1.64 & 0.30 & 21.37 \\
\hline \multirow[t]{4}{*}{$<2 \mu \mathrm{m}$} & GEC5a & 43.44 & 0.72 & 16.19 & 7.47 & 0.10 & 2.55 & 10.19 & 0.21 & 1.98 & 0.12 & 17.03 \\
\hline & GEC7a & 44.73 & 0.75 & 17.11 & 8.03 & 0.18 & 2.63 & 6.49 & 0.23 & 2.05 & 0.14 & 17.66 \\
\hline & GEC8a & 43.08 & 0.69 & 16.61 & 7.47 & 0.17 & 2.71 & 7.18 & 0.30 & 2.09 & 0.13 & 19.57 \\
\hline & $x$ & 43.75 & 0.72 & 16.64 & 7.66 & 0.15 & 2.63 & 7.95 & 0.25 & 2.04 & 0.13 & 18.09 \\
\hline
\end{tabular}

sites. Because of the coarse grains of the temper present in the archaeological samples, optical microscopy gave useful petrographic data to compare archaeological samples and pelitic sediments $[17,23]$.

\subsection{Raw materials provenance}

There is a good correspondence between mineralogical and petrographic data of pottery temper and raw materials psammitic fraction. Heavy minerals and trachytic fragments occurring in both ceramics and alluvial deposits are quite common in Roman magmatic province (RMP) [24,25]. The Tavoliere plain falls geographically in the tephra dispersion lobes of several volcanoes belonging to RMP, which erupted trachytic products (e.g., Mt. Vulture, Phlegrean Fields, Roccamonfina, Somma-Vesuvius, etc.). The sedimentary components of the ceramics (quartzarenite, chert, limestone and clays) are consistent with those outcropping along the drainage basins of the Celone River [26,27].

Extending the comparison to the elemental data, one can see in the ternary diagram CSA (Fig. 5) that neither the Alluvial deposits nor the Argille subappennine compositions fit well with those of ceramics. Although both group F and group $\mathrm{M}$ are richer in $\mathrm{CaO}$ than ceramics, samples belonging to group $\mathrm{F}$ are aligned both with ceramics and kiln fragments. Their compositions fall in a triangle having $75-80 \% \mathrm{SiO}_{2}$ as minor side and $100 \% \mathrm{CaO}$ as opposite corner. The compositional interval $75-80 \% \mathrm{SiO}_{2}$ concerns with that of clay minerals which represent, in addiction with carbonates $(\mathrm{CaO}$ corner), the main components of these materials. The difference of $\mathrm{CaO}$ content between whole samples and clayey fractions in group F concerns to carbonates content in the coarser fractions as shown by optical microscope observa- tions. Although both sediments groups contain clay-sized calcite, the compositional variability of alluvial deposits instead of Argille subappennine homogeneity does not exclude Ca-poor clays occurrence in river deposits. The main objective of the sampling was to verify the compatibility between non-plastic inclusions occurring in the ceramic bodies and kiln fragments with the sand-size fraction of possible local raw materials. Summarising, non-plastic inclusions occurring in the archaeological samples are consistent with those of alluvial deposits. In addition, the kiln's wall fragments have a coarser texture and chemical composition similar to alluvial deposits (Ca-rich), whereas the ceramics have a Ca-poor clay matrix and scarce carbonate rock fragments. The chemical trend shown by the archaeological materials

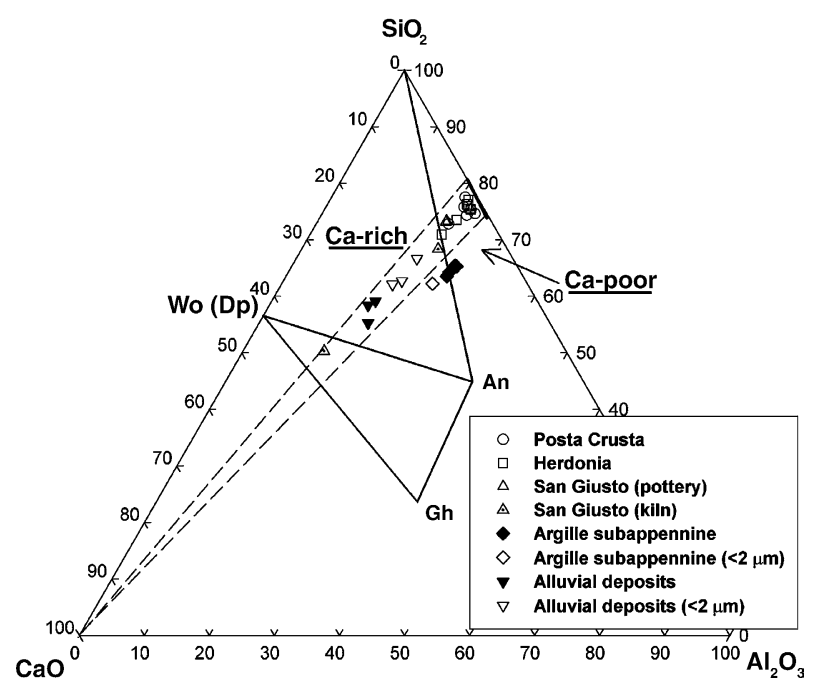

Fig. 5. Ceramic triangular diagram $\mathrm{CaO} / \mathrm{Al}_{2} \mathrm{O}_{3} / \mathrm{SiO}_{2}$ of archaeological and pelitic samples. Wo, wollastonite; Dp, diopside; Gh, gehlenite; An, anortite. 
and the alluvial deposits (Fig. 5) suggests the use of similar materials having different contents of carbonates. Since the Argille subappennine are marly clays showing regional compositional homogeneity $[28,29]$ they do not consist with the Ca-poor clay matrix of ceramics. Though sampled alluvial deposits do not have a non-calcareous clay fraction, petrographical and textural data confirm the hypothesis of their use as raw materials for both ceramics and kiln. A more extended local sampling both in space and in time (i.e. ancient deposits dated by archaeological materials) will give further information about available raw materials.

Although alluvial deposits were used as raw materials for pottery production and kiln building, because of quite similar geological features throughout the Tavoliere area, it is not possible to point out which one(s) of the rivers (e.g. Celone, Carapelle, Cervaro, etc.) furnished the raw material.

In the case of S. Giusto, because of its position at the confluence of Celone and Jorenzo rivers, local provenance can be assessed. Since there are no references on kilns materials and alluvial deposits concerning Posta Crusta and Herdonia, an analogous raw material exploitation can be supposed. Although in the Tavoliere area there are clays of better quality for the ceramic production (i.e., Argille subappennine), in the late Roman figline, potters employed raw materials immediately available for common ware production.

\subsection{Technological aspects}

Optical microscope observations showed that all pottery samples have a dark core and a high birefringent oxidised border, except for sample SG2 that was fired in reducing atmosphere. High birefringence is due to clay minerals present in the matrix not completely decomposed by firing (as revealed by PXRD analyses) and the dark core displays an incomplete oxidation of the original organic matter and of the free iron phases. Textural features relates to a medium synterization grade. PXRD data (Table 2) show that the temperature reached was below $800^{\circ} \mathrm{C}$ : primary calcite, illite and smectite more strong intensities (001) peaks occur in various amounts.

The colour pattern showed by the sherds (i.e. dark core-orange border) gave some information on the firing conditions. The zoning of ceramic body suggests variability of firing atmosphere (i.e. oxidising or reducing) in a traditional kiln. External oxidation of the sherds is related to the last period of the firing (i.e. cooling), when no more fuel was supplied and oxidation occurred [30].

Medium synterization grade and non-calcareous coarse temper represented good technological choices to enhance the thermal shock resistance of the pots and to avoid lime spalling [31,32].

\section{References}

[1] S.M. Cassano, R. Laviano, I.M. Muntoni, Pottery technology of early Neolithic communities of Coppa Nevigata and Masseria Candelaro (Foggia, Southern Italy), in: B. Fabbri (Ed.), The Cultural Ceramic Heritage, Fourth Euro Ceramics, 14, Gruppo Editoriale Faenza Editrice, Faenza, 1995, pp. 137-148.

[2] S.T. Levi, A. Cazzella, M. Moscoloni, F. Fratini, M.L. Amadori, E. Pecchioni, S. Conticelli, R. Cioni, Analisi archeometrica della ceramica dell'età del Bronzo di Coppa Nevigata (FG): alcune implicazioni archeologiche, Scienze dell'Antichità-Storia, Archeologia, Antropologia 8-9 (1994-1995) 101-160.

[3] E. Antonacci Sanpaolo, L. Follo, S. Sfrecola, Alcuni aspetti tecnologici della ceramica policroma della Daunia nella Collezione Sansone di Mattinata (FG). L'apporto dell'archeometria, Atti dell' $11^{\circ}$ Convegno Nazionale sulla Preistoria-Protostoria-Storia della Daunia, Gerni Editore, San Severo, 1990, pp. 139-170.

[4] G. Volpe, Contadini, pastori e mercanti nell'Apulia tardoantica, Edipuglia, Bari, 1996.

[5] G. Volpe, Paesaggi della Puglia tardoantica, Atti del XXXVIII Convegno di Studi sulla Magna Grecia (Taranto 1998), L'Italia meridionale in età tardoantica, 1999, Istituto per la storia e l'archeologia della Magna Grecia, Taranto, 1999, pp. 267-329.

[6] M. Caldara, L. Pennetta, Nuovi dati per la conoscenza geologica e morfologica del Tavoliere di Puglia, Bonifica VIII (1993) 25-42.

[7] J. Mertens, G. Volpe, Herdonia. Un itinerario storico-archeologico, Edipuglia, Bari, 1999.

[8] G. Volpe (Ed.), Ordona X. Ricerche archeologiche a Herdonia (scavi 1993-1998), Edipuglia, Bari, 2000.

[9] G. De Boe, Villa romana in località Posta Crusta. Rapporto provvisorio sulle campagne di scavo 1972 e 1973, Notizie degli Scavi di Antichità 24 (1975) 516-530.

[10] G. Volpe, J. Mertens, Il territorio, la viabilità, la produzione agraria, in: J. Mertens (Ed.), Herdonia. Scoperta di una città, Edipuglia, Bari, 1995, pp. 291-320.

[11] C. Annese, Le ceramiche tardoantiche della domus B, in: G. Volpe (Ed.), Ordona X. Ricerche archeologiche a Herdonia (scavi 19931998), Edipuglia, Bari, 2000, pp. 285-342.

[12] M. Turchiano, La cisterna e il suo contesto. Materiali tardoantichi dalla domus B, in: G. Volpe (Ed.), Ordona X. Ricerche archeologiche a Herdonia (scavi 1993-1998), Edipuglia, Bari, 2000, pp. 343-385.

[13] D. Leone, Le ceramiche tardoantiche della fattoria di Posta Crusta, in: G. Volpe (Ed.), Ordona X. Ricerche archeologiche a Herdonia (scavi 1993-1998), Edipuglia, Bari, 2000, pp. 387-432.

[14] G. Volpe (Ed.), San Giusto, la villa, le ecclesiae, Primi risultati dello scavo nel sito rurale di San Giusto (Lucera): 1995-1997, Edipuglia, Bari, 1998.

[15] G. Volpe, Linee di storia del paesaggio dell'Apulia romana: San Giusto e la valle del Celone, in: E. Lo Cascio, D. Storchi Marino (Eds.), Modalità insediative e strutture agrarie nell'Italia meridionale in età romana, Atti del Convegno Internazionale (Napoli 1998), Edipuglia, Bari, 2001, pp. 315-361.

[16] N. Cuomo Di Caprio, La ceramica in archeologia. Antiche tecniche di lavorazione e moderni metodi di indagine, L'Erma di Bretschneider, Roma, 1985.

[17] M. Maggetti, Phase analysis and its significance for technology and origin, in: J.S. Olin, A.D. Franklin (Eds.), Archaeological Ceramics, Smithsonian Institution Press, Washington, 1982, pp. 121-133.

[18] M. Franzini, L. Leoni, M. Saitta, Revisione di una metodologia analitica per fluorescenza X, basata sulla correzione completa degli effetti di matrice, Rendiconti della Società Italiana di Mineralogia e Petrologia 31 (1975) 356-378.

[19] R. Laviano, Analisi mineralogica quantitativa di argille mediante diffrattometria di raggi X, Procedure di analisi di materiali argillosi, ENEA, Roma, 1987, pp. 215-234.

[20] R. Kretz, Symbols for rock-forming minerals, American Mineralogist 68 (1983) 277-279. 
[21] P. Pieri, L. Sabato, M. Tropeano, Significato geodinamico dei caratteri deposizionali e strutturali della Fossa Bradanica nel Pleistocene, Mem. Soc. Geol. It. 51 (1996) 501-515.

[22] L. Dell'ana, M. Di Pierro, G. Nuovo, G. Ciaranfi, G. Ricchetti, Puglie, Giacimenti di argille ceramiche in Italia, in: F. Veniale, C. Palmonari (Eds.), Gruppo Italiano A.I.P.E.A, Rome, (1974) 195-234.

[23] P. Schubert, Petrographic modal analysis. A necessary complement to chemical analysis of ceramic coarse ware, Archaeometry 28 (1986) $163-178$.

[24] A. Peccerillo, Roman comagmatic province (central Italy): evidence for subduction-related magma genesis, Geology 13 (1985) 103-106.

[25] M. De Fino, L. La Volpe, A. Peccerillo, G. Piccarreta, G. Poli, Petrogenesis of Monte Vulture volcano (Italy): inferences from mineral chemistry, major and trace element data, Contrib. Mineral. Petrol 92 (1986) 135-145.

[26] L. Dazzaro, S. Di Nocera, T. Pescatore, L. Rapisardi, M. Romeo, B. Russo, M.R. Senatore, M. Torre, Geologia del Margine della catena appenninica tra il F. Fortore e il T. Calaggio (Monti della Daunia-Appennino Meridionale), Mem. Soc. Geol. It. 41 (1988) $411-422$.
[27] L. Dazzaro, L. Rapisardi, Osservazioni geologiche sull'Appennino Dauno, Mem. Soc. Geol. It. 38 (1987) 241-246.

[28] F. Balenzano, L. Dell'Anna, M. Di Pierro, Ricerche mineralogiche, chimiche e granulometriche su argille subappennine della Daunia (Puglia), Geologia Applicata e Idrogeologia XII (1977) 33-55.

[29] M. Dondi, B. Fabbri, R. Laviano, Characteristics of the clays utilized in the brick industry in Apulia and Basilicata (Southern Italy), Mineralogica Petrographica Acta XXXV (1992) 181-191.

[30] J.C. Echallier, Eléments de technologie céramique et d'analyse des terres cuites archéologiques, Documents d'archéologie méridionale, Lambsec (1984).

[31] R.B. Heimann, Assessing the technology of ancient pottery: the use of ceramic phase diagrams, Archeomaterials 3 (1989) 123-148.

[32] M. Tite, V. Kilikoglou, G. Vekinis, Strength, toughness and thermal shock resistance of ancient ceramics, and their influence on technological choice, Archaeometry 43 (2001) 301-324. 